\title{
Jadwiga Szymaniak
}

Gdańska Wyższa Szkoła Humanistyczna

Filia w Koszalinie

\section{Sprawozdanie z Kongresu Pedagogicznego (Wolfsburg 2015)}

W dniach 6-8 listopada 2015 roku, a więc jeszcze przed tragicznym zamachem terrorystycznym we Francji, zorganizowano w Niemczech kolejny już wielki kongres poświęcony przede wszystkim kształceniu (Großer Lehrer-Bildungskongress Beltz Forum) w kontekście ważnych i aktualnych problemów. Inkluzja, zmiana paradygmatów kształcenia, rola wartości i potrzeb egzystencjalnych po obu stronach dydaktycznego procesu, mobbing, ADHD, niezrozumienie ze strony rodziców to tylko niektóre zjawiska, którym starano się przyjrzeć z zaangażowaniem i uwaga.

Sądzę, że wartość tego typu spotkań związana jest, $z$ jednej strony, z próba doprecyzowania niektórych pojęć, torujacych droge nowemu myśleniu o edukacji (myślę tu m.in. o inkluzji czy kreatywności), z drugiej strony $-z$ umiejętnościa zaprezentowania interesujacych rozwiazań praktycznych w trakcie warsztatów. Tak też było w Wolfsburg. Podczas trwania Kongresu Pedagogicznego zorganizowano ponad 50 zajęć warsztatowych, wykładów i spotkań dyskusyjnych, które odbywały się na terenie nowoczesnego Parku Kongresowego (częściowo jeszcze w budowie).

Na kongresie znalazłam się na zaproszenie istniejacego od 175 lat wydawnictwa Beltz, zasłużonego w dziedzinie promowania ksiażek o tematyce pedagogicznej, wydawcy obszernego „Beltz Lexikon Pädagogik” (2012) czy specjalistycznego słownika z zakresu pedagogiki szkolnej (Neues schulpädagogisches Wörterbuch, 2013).

Sprawozdanie zacznę od omówienia wystąpień precyzujących pojęcia, bowiem wniosły one wiele impulsów do przemyśleń i były bardzo żywo przyjmowane. Pojęcie inkluzji, tak istotne w międzynarodowej debacie, omówił związany $z$ uniwersytetami w Kassel oraz Hamburgu prof. dr Heinz Bude w wystapieniu „Im Spannungsverhältnis von Inklusion 
und Exklusion”. Jako socjolog łączy on pojęcie inkluzji z pojęciem społeczeństwa służby (niem. Dienst-Gesellschaft), ale jednocześnie, co ważne $z$ pedagogicznego punktu widzenia, z dokonująca się rewolucja kompetencji, także w kierunku wspomagania potrzebujacych. Wyzwaniom tym sprostać musi odpowiedni system kształcenia, szczególnie nauczycieli. Niemiecki system kształcenia, zwłaszcza młodzieży, profesor ocenił jako mało jeszcze dostosowany do zachodzacych zmian, dokonujacy zbyt wczesnej selekcji, tuż po kształceniu na szczeblu poczatkowym. Wykazał aktualny związek między kryminalizacja a słabym kształceniem. Kształcenie, jak wskazywał, to umocnienie osoby (Stärkung der Person). Apel o jego modyfikację wyartykułowany przez prof. Heinza Bude wydaje się bardzo zasadny, dotyka potrzeb uniwersalnych, podobnie jak postulat przebudowy świadomości w myśl humanistycznej zasady: „Jeśli wygrywasz - podaj rękę”. Prelegent zakończył swoje wystąpienie podkreśleniem rosnacej odpowiedzialności nauczycieli. Według niego, największą odpowiedzialnościa jest sprostanie indywidualnemu podejściu do każdego z wychowanków.

Wystapienie prof. H. Bude zainaugurowało obrady plenarne i zakończyło się dużą owacją. Słuchacze dziękowali prelegentowi za wyrażone myśli, które świadczyły o wielkim zaangażowaniu, a w dyskusji podkreślali tematykę etyki szkoły i uczelni, mówili o duchu szkoły i podkreślali troskę o profesjonalny habitus nauczających na każdym szczeblu. Obrady plenarne w drugim dniu spotkania zainaugurowało wystapienie prof. dr Michaeli Brohm w tandemie $z$ dr. Wolfgangiem Endresem. Sa oni współautorami cennego podręcznika „Positive Psychologie in der Schule” (2015).

W prelekcji „Positive Psychologie in der Schule - Der Glücksfaktor im Schulalltag” przedstawiono kilka wybranych aspektów psychologii pozytywnej. Prof. Michaela Brohm (zajmujaca się dydaktyka na Uniwersytecie w Trier) rozwinęła teze „Die Menschen wollen wachsen” („Ludzie chca rosnąć...”). Odwoływała się w wystapieniu do prostych przykładów ze szkolnego życia. Na przykład zadania domowe, które zadajemy wychowankom, nie moga być nudne i wykonywane powierzchownie. Autorzy przestrzegali też przed rodzeniem się „wyuczonej bezradności” u dzieci, odwoływali do zestawu licznych ćwiczeń „wzmacniajacych” ze swojego podręcznika, opartych na filozoficznych kategoriach nadziei i wdzięczności. 
Uczestników kongresu spotkała wielka niespodzianka - prof. Michaela Brohm zagrała na wiolonczeli mimo zmęczenia spowodowanego obszerna prelekcją. Jak przyznała, uczy się gry na tym instrumencie dopiero dwa lata. Ale to zmaganie się $z$ instrumentem wyzwala energię i daje jej radość. Wystapienie zakończyło się owacja na stojąco.

Ważne zagadnienie kreatywności poruszył w przygotowanych przez siebie materiałach Olaf - Axel Burow, profesor nauk o wychowaniu na Uniwersytecie Kassel. Nie byłam świadkiem jego wystapienia (odbywało się w ramach seminariów praktycznych i warsztatów w drugim dniu kongresu), korzystam więc $\mathrm{z}$ zapisu zamieszczonego w materiałach kongresowych, które otrzymał każdy uczestnik. Zaciekawić już może motto rozważań wzięte $z$ pism Johna Deweya: „Znaleźć to, do czego się nadajemy, znaleźć sposobność, aby to czynić, to klucz do szczęścia”. Badacz przedstawił, także w świetle własnych poszukiwań, wiele kontrowersyjnych konstatacji, niepozbawionych jednak słuszności. Minął czas nauczyciela - samotnego bojownika -stwierdził.

Globalizacja i digitalizacja wymagają od pedagogów przede wszystkim umiejętności kooperacji, aby rozwinęli swój potencjał i kreatywność. Wypowiedź prof. Olafa Burowa zawiera krytyczne uwagi pod adresem niektórych upowszechnionych praktyk, na przykład oceniania osiagów uczniów tylko standardowym pomiarem. Postępy szkolne nie sa w wielu krajach znacząco lepsze, nie osiagnięto celów zakreślonych niegdyś w Bolonii, a międzynarodowe, prowadzone od lat studia typu PISA wykazują słabe osiagi w niektórych dziedzinach i, co ważne, sa bardzo silnie zwiazane $z$ pochodzeniem społecznym badanych. Prof. Burow wiaże te niepowodzenia $z$ kierunkiem, który zmierza do uzyskania wzrostu rezultatów szkolnych zwłaszcza poprzez zewnętrzne żąania i podniety. Wykazuje błędność tych założeń, wręcz ich kontraproduktywność. Jak pisze, „kreatywność i szczytowe osiagnięcia [...] powstaja przez odkrycie i urzeczywistnienie tego, co dla nas rzeczywiście jest ważne i porusza nas wewnętrznie". Nawiązuje tu do zapomnianej tradycji - od Arystotelesa, poprzez Johna Locke'a, Benjamina Franklina, do Immanuela Kanta. Zwłaszcza Kant silnie podkreślał, że możliwe jest głębokie zadowolenie $z$ uczenia się i poszerzania swoich horyzontów. „Z radościa zdobyta wiedza i mądrość czyni człowieka szczęśliwym" - akcentowali wymienieni wielcy pedagogowie i filozofowie. Warto też jeszcze przytoczyć za prof. Bu- 
rowem zdanie Ernsta Trappa (1745-1818) wykładowcy na pierwszej katedrze pedagogiki w Halle, który napisał: „Wychowanie jest kształceniem człowieka do szczęścia”. Dziś pojęcia szczęścia nie ma jednak w słownikach pedagogicznych, a to, co przeczuwali Locke, Franklin, Kant i Dewey, obecnie udowadniają badania mózgu. Naciski, wymagania zewnętrzne powoduja blokady w myśleniu i działaniu. Uczenie się jest wtedy trudniejsze. Motywujące okazuje się, w świetle badań prof. Burowa, doświadczanie wspólnych osiagnięć, szanowanie wartości, zaufanie. Wtedy rodza się kształcące wyzwania, które czynią nas kreatywnymi.

Wielu pozytywnych odczuć doznałam już w pierwszym dniu kongresu, uczestniczac w zajęciach prowadzonych przez dra Clausa Kocha, wykładowcy z Bielefeld, który przygotowany przez siebie materiał poświęcił zmianie paradygmatu w spojrzeniu na dziecko i dorastających. Nowe odkrycia psychologii rozwojowej z ostatnich 30 lat doprowadziły do teorii relacji ujmujacych dziecko jako ich uczestnika, ważnych szczególnie w kontaktach $z$ osobami znaczacymi. Nacechowane troska o wartości i potrzeby egzystencjalne dorastajacych rozważania dra Clausa Kocha podkreślały konieczność empatycznego i subtelnego reagowania uczacych w tych relacjach. Proces „rezonansu”, jaki rodzi się we wspólnej przestrzeni, powodować może wzajemne uznanie, wzajemne uczenie się i rozwój, także po stronie prowadzacych dydaktyczny proces.

Dr Claus Koch zwrócił uwagę szczególnie na dzieci mające różnego rodzaju trudności, na przykład z poczuciem winy, z zaburzeniami koncentracji, $z$ asocjalnym zachowaniem. Dzieci takie (w literaturze niemieckojęzycznej funkcjonuje określenie herausforderdne Kinder - dzieci potrzebujące wsparcia) cierpia głównie $z$ powodów związanych $z$ ich wczesnym dzieciństwem, na przykład $z$ powodu rozłąki $z$ rodzina, $z$ licznymi wyjazdami i zmiana szkoły. Przypominaja się tu nasze polskie "eurosieroty”. Ich problemy na ogół pozostaja niewypowiedziane, a uzewnętrzniaja się $\mathrm{w}$ nieracjonalnych zachowaniach, czasem też w chęci nadmiernego przystosowania się, uległości. Pedagogowie, także przygotowujący się do tego zawodu, mają więc trudne zadanie, aby zinterpretować ich sens. Problem stanowić będa wzajemne relacje, a nie tylko zachowania podopiecznych.

Pedagog jako dorosły ponosi odpowiedzialność za jakość relacji, powinien bowiem $z$ racji swojej wiedzy i odbytych studiów posiadać klucz do problemu i próbować go konstruktywnie rozwiąać, na co potrzebny jest 
czas. Apel dra Clausa Kocha o kulturę obchodzenia się z takimi problemami w szkole, o ujęcie szkoły jako terenu wzajemnych relacji i „rezonansu" - wydaje się nader istotny, także w kształceniu studentów.

Ponieważ interesuje mnie przede wszystkim pedagogika szkolna, zwrócę uwagę na niektóre materiały $z$ tej dziedziny zamieszczone w obszernym portfolio, które otrzymał każdy uczestnik kongresu. Prof. dr Ludwig Haag reprezentujący Katedrę Pedagogiki Szkolnej Uniwersytetu w Bayreuth zasygnalizował pojęcie Classroom Management, sformułowane na gruncie amerykańskim, oznaczajace „prowadzenie klasy” (materialy nosza tytuł Erfolgreich unterrichten mit Classroom Management). Centralnym wymogiem w zakresie prowadzenia klasy wydaje się obchodzenie $z$ różnorodnościa, a tym samym dokonywanie diagnozy indywidualnych przypadków. W zakresie prowadzenia klasy prof. Haag zwrócił uwagę zarówno na niezbędne w tym zakresie (w dalszym ciagu) niektóre założenia behawioralne wobec uczniów (np. jasny system regul, wzmocnienia), jak i nieco późniejsze, z lat 70. założenia ekologiczne (profilaktyka zakłóceń, znajomość zadań rozwojowych stosownych do wieku, „klimat” wzajemnego zaufania). Skoncentrował się jednak na modelu pracy skierowanym na poszczególne osoby, który akcentuje przede wszystkim rosnąca stopniowo niezależność uczniów od nauczycieli, wiąże się z ich odpowiedzialnościa za wyniki. Mówi się w tym zakresie nawet, jak zaznaczył prof. Haag, o nowym paradygmacie. Idzie on w parze $z$ odmiennym rozumieniem nauczania i uczenia się. Powołując się na książkę, której jest współautorem (Klassenführung, Beltz 2012) Ludwig Haag akcentuje wagę uzewnętrzniania własnych poglądów przez dorastajacych, demonstrowania przez nich swoich przekonań, które kształtują się w relacjach $z$ innymi, poprzez sprawdzanie argumentów i osobiste zaangażowanie. Zaznacza: „Prowadzenie klasy to ważny temat kształcenia uniwersyteckiego, jak i ustawicznego nauczycieli, istotny dla ich rozwoju. Zawsze jednak w zmaganiu się $z$ pytaniem o cele wychowania, bo one stanowia jądro, istotę problemu". Ta troska o wartości przewijała się także w wielu innych materiałach i podczas innych zajęć. Zwrócę uwagę na materiał opracowany przez dra Elmara Philipa, pedagoga zajmującego się doradztwem i kształceniem ustawicznym. W szkicu Multiprofessionelle Teamentwicklung - Erfolgfaktoren für die Zusammenarbeit in der Schule zajał się zwłaszcza pojęciem wzajemnego zaufania. Powołując się na wyniki badań amerykańskich 
i Johna Hattie ukazał zaufanie jako decydujacy czynnik w pracach zespołów specjalistów, które troszcza się w szkole (także w Polsce) o rozwój jednostek potrzebujących pomocy. Do kompetencji osób pomagajacych zaliczył przede wszystkim umiejętność słuchania, wyróżniając różne jej stopnie. Apelował w tym kontekście o „inteligencję serca” wobec osoby lub grup, z którymi się pracuje. Ze słuchania rodzi się wtedy empatyczne „wsłuchiwanie się”. Dr Elmar Philipp radzi skupić się na kilku aspektach $\mathrm{w}$ toku pracy $\mathrm{z}$ jednostkami i grupami w szkołach, na przykład na budowaniu identyfikacji $z$ dana placówka, budowaniu postawy otwartości i empatii oraz tolerancji dla błędu, ale przede wszystkim dokonaniu prób zmiany perspektywy ze strony pedagogów (słynne wejście w mokasyny innego). I nie chodzi tu o patrzenie przez „różowe okulary” czy, przeciwnie, o „okulary na deficyt”, ale o „okulary na szanse”. Udaje się to w szkołach prowadzonych $z$ troska o realizację tych zamierzeń, gdzie zespoły osób pomagajacych (wszak istnieją i w naszych placówkach) łączy autentyczna troska o rezultaty i istnieja po temu realne warunki (godziny umieszczone w planie zajęć i pomieszczenie).

Obecni na kongresie czynni nauczyciele gimnazjum, dr Gabrielle Kuen i Anton Schwarzmann, współpracujacy z Wydawnictwem Beltz autorzy podręczników, silnie zaakcentowali w swoim materiale tematykę aksjologiczna, podbudowując ja starannie przeprowadzonymi badaniami. Uczniowie gimnazjum, jak wynika $z$ poszukiwań autorów, nie chca być postrzegani tylko jako „odbiorcy”, ale jako jednostki, osoby. Marza, aby nauczyciele zdjęli $z$ nich uczucie bezradności, którego niejednokrotnie doświadczają. Wybór metod pracy lekcyjnej, zdaniem badanych, jest ważny, ale drugorzędny. Nie wszystkie metody „pasuja” do uczących się i nauczajacych. Klasyczny wykład może być tak samo istotny jak inne formy pracy. Jak stwierdzają dr G. Kuen i A. Szchwarzmann „Tylko niewiele zawodów rozwija się tak intensywnie we wzajemnych relacjach różnych osobowości, jak nauczycielski”. Ich badania dowiodły, że uczniowie cenia nauczycieli, u których wyczuwa się pewien idealizm w działaniach, chęć dania uczniom radości. To inspirujący wskaźnik i ważny trop.

W podobnym duchu utrzymane były wypowiedzi innych nauczycieli, na przykład dr Danieli Lund (współpracujacej z Instytutem Kształcenia Zawodowego i Pedagogiki Gospodarczej Uniwersytetu w Hamburgu) i Ernesta Lunda, którzy stwierdzili: „Rozwój szkoły potrzebuje ludzi. Te- 
maty i cele można podać. Prawidłowo ułożyć projekty, ale ludzie musza je dla siebie uczynić własnymi. Powinny stać się sprawa serca”. Autorzy odwołuja się tu do wielokrotnie przewijającego się na kongresie pojęcia „pola rezonansu”, do aspektów psychologii pozytywnej w ujęciu Martina Seligmana i Michaeli Brohm, a także do wyników badań PISA i Johna Hattie. Sa przekonani, że nie dokona się zmiany kultury szkolnej tylko poprzez krytykę nauczycieli i szkoły. Akcentuja kulturę współbycia (niem. Beziehungskultur), obejmująca tolerancję, poszanowanie wartości i empatię. Nieodparcie nasuwają mi się tu postulaty nieżyjacej już nauczycielki i autorki licznych prac pedagogicznych, dr Bronisławy Dymarowej, która kulturze współbycia poświęciła wiele cennych publikacji i inspirowała liczne grono pedagogów zainteresowanych ta tematyka na Uniwersytecie Śląskim i nie tylko. W swoich rozważaniach dr D. Lund i E. Lund odnieśli się do pojęcia „treningu umiejętności refleksji” (Training der Refleksionsfähigkeit). Jest on, ich zdaniem, oczywista częścia wykształcenia pedagogicznego (poprzez rozmowy, wzajemne słuchanie, doradztwo). Ten akcent na zmianę kultury szkolnej i uczenia się (Lernkulturwandel) będzie, jak sądzę, kontynuowany na następnych spotkaniach kongresowych.

Wypada poświęcić również kilka uwag zajęciom warsztatowym. Stanowiły one znaczacy procent w ogólnym bilansie zajęć. Już w pierwszym dniu kongresu uczestniczyłam w warsztatach prowadzonych przez dra Hoegga Günthera, prawnika, znawcy prawa szkolnego. Zajęcia poświęcone były „trudnym” rodzicom. Jak wynika ze szkolnej praktyki i obserwacji, pewne sytuacje konfliktowe w zakresie współpracy z rodzicami występuja na wszystkich etapach kształcenia dzieci. Powtarzaja się pretensje i zarzuty. Prowadzacy prezentował typowe pytania padające, najczęściej, kiedy jest już za późno, ze strony rodziców, na przykład: „Co pani chce od mojego dziecka?”, „Co ono może jeszcze zrobić, aby dostać dobra ocenę na koniec roku szkolnego?”. Dr Günther zaakcentował rolę pytań konkretnych, rozpoczynających się od „kto?”, „kiedy?”, „gdzie?”, ukazując ich znaczenie w poszczególnych sytuacjach, najczęściej wiążących się z mobbingiem. Z zajęć wypłynęły ważne wnioski, między innymi: „nauczyciel nie może sprzedać się za tanio", szczególnie w sytuacji napiętej, jak ta, która wiaże się z pozytywna ocena całoroczna $z$ przedmiotu. Nie wystarczy wtedy, aby uczeń przedstawił referat skopiowany z Internetu, powi- 
nien natomiast osiagnać pozytywną ocenę ze sprawdzianu i przedłożyć systematycznie prowadzony lub uzupełniony zeszyt.

Nawet ten dość pobieżny przegląd materiałów kongresowych wskazuje na bogactwo poruszonych problemów. Odniosłam się tylko do wybranych tematów, najczęściej do zajęć, w których uczestniczyłam. Jednak obszerny materiał kongresowy, który otrzymaliśmy, pozwala na swobodny dostęp do całości poruszanych zagadnień. Uczestnicy zajęć mieli możliwość nabycia pomocy dydaktycznych i książek.

Następny kongres odbędzie się 11 i 12 listopada 2016 roku w Weinheim i będzie poświęcony, jak wynika z zapowiedzi, „nauczaniu w trudnych czasach". Będzie również powiązany z obchodami jubileuszu 175 lat istnienia Wydawnictwa BELTZ. 